\title{
INFORMATION AND RESEARCH CENTER OF THE PUBLIC FINANCE AND TAX LAW OF CENTRAL AND EASTERN EUROPEAN COUNTRIES - AN ASSOCIATION AT THE FACULTY OF LAW, THE UNIVERSITY OF BIALYSTOK
}

The Information and Research Center of The Public Finance and Tax Law of Central and Eastern European Countries is an association at the Law Faculty of the University of Bialystok. It is registered in National Court Register in the XII Department of the District Court in Bialystok, under no. 0000136524.

The main objectives of the Association are to gather information about scientific activities of its members, exchange information, introduce common research and conference initiatives, and to support the achievement of these goals. The Association develops exchange of information among research and university centres in Poland and around the world, initiates cooperation with institutions in Poland and cooperates with the government and non-governmental organizations. One of the crucial goals of its activity is to promote European standards in the fields of public finance and tax law in Poland as well as in the countries represented by the members of the Association, and to share experiences with other countries. The Association focuses also on publishing activity and the organization of workshops, seminars and conferences. The main aspect of the activity of the Association is the support of research exchange between scientific centres in Eastern and Western Europe. Among its members, the Association assembles distinguished scholars and academics specializing in public finance and tax law as well as in related fields from Poland and abroad.

The Scientific Council of the Association is comprised of the following members: Prof. Cezary Kosikowski (Poland) - President of the Council, Doc. Lilia Abramchik (Belarus), Prof. Vladimiŕ Babčak (Slovakia), Prof. Elżbieta Chojna-Duch (Poland), Prof. Andrzej Drwiłło (Poland), Prof. Jadwiga Glumińska-Pawlic (Poland), Dr Edward Juchniewicz (Poland), Prof. Marina Valentinovna Sentsova (Russia), Prof. Jerzy Małecki (Poland), Dr Jarosław Marczak (Poland), Prof. Wiesława Maria Miemiec (Poland), Dr Petr Mrkývka (Czech Republic), Oksana Muzyka-Stefanchuk (Ukraine), Prof. Zbigniew Ofiarski (Poland)

Prof. Alicja Elżbieta Pomorska (Poland), Doc. Maria Żuk (Belarus).

The President of the Association is Professor Eugeniusz Ruśkowski, Vice President - Professor Leonard Etel, Secretary - Agnieszka Stryjewska. 
So far, the Association has initiated several scientific international conferences. It organized (jointly with the University of Finance and Management in Bialystok) an international conference "Methods and Instruments of Limiting Public Debt and Budget Deficit in Countries of Central and Eastern Europe" which, was held from 19 to 21 September 2002 in Bialystok, and a conference "Tax and Local Fees Reforms - Polish and Selected European Countries Experiences" (Bialowieza, November 26$27,2002)$. The materials from the conferences were published in a book-form after the events.

In 2003, the next initiative of the Association undertaken jointly with the Law Department of the University in Brno, was the organization of an international conference "Problems of Public Finance and Tax Law in Central and Eastern European Countries before the accession to the European Union". In the event scholars from six countries of the Central and Eastern Europe participated and exchanged their views on problems with application of the tax law in their countries.

The Association also cooperated in the organization of the III ${ }^{\text {rd }}$ international finance conference of Central and Eastern European countries, which took place on September 23-24, 2004 in Vilnius, and examined the problems of the financial law evolution in our region of Europe. The IV ${ }^{\text {rd }}$ scientific conference of the same scope took place on August 29-30, 2005 at Šafarik University in Košice (Slovakia), and it was devoted to the current problems of public finance and tax law in Central and Eastern Europe. Successive conferences were organized in Grodno (Bielarus) and Voronezh (Russia).

Beginning from 2002 the Association has coorganized with the Ministry of Finance and the Regional Chamber of Audit in Bialystok annual conferences concerning local taxes and fees (in Bialowieza and Augustow).

In the first quarter of 2004, the Board of the Association initiated the process of achieving the status of a public benefit organization. In consequence, such a status on April 30, 2004, which means that the "Center" can apply for funds supporting its activities from the local governments as well as from the European Union. The public benefit organization status also allows receiving funds from individuals who can pass $1 \%$ of their yearly income tax to such organizations.

In addition, the members of the Association conduct a number of research projects, the last of which was implemented in 2005-2006. It concerned the problems of the development and application of tax law in Poland with particular stress on the control of these processes. The research was carried out by about 30 members of the Association and financed by the State Committee for Scientific Research (currently - the Ministry of Science and Higher Education). Two conferences were strictly connected with this project. The first one - an international conference which took place on September 16-17, 2006 at the University in Grodno (Belarus) was 
titled: "Establishing and implementation of financial law in Central and Eastern European countries". The second one - "The control of tax law establishment and implementation under the Constitution of the Republic of Poland" summarized the research mentioned above and was held at the Faculty of Law at the University of Bialystok on October 27, 2006. The main conclusions of the research were presented in a publication of the same title, edited by prof. E. Ruśkowski (Wolters Kluwer Press, Warsaw 2006).

Moreover, the Association supported and participated in negotiations on contracts of cooperation between the University of Bialystok and Safarik University in Kosice, Masaryk University in Brno, and the Lithuanian University of Law in Vilnius.

The "Center" also actively helps its foreign members by: enabling them to publish in Polish scientific periodicals, journals and books, distributing Polish professional financial magazines abroad and preparing scientific research scholarships and grants in Poland.

In 2006/2007, the Board of the Association, apart from its regular activity, introduced other new initiatives, in particular:

- admitted new members to the "Center" from the countries of Central and Eastern Europe, which haven't represented in our organization before;

- actively attended the $\mathrm{VI}^{\mathrm{th}}$ international finance conference of Central and Eastern European countries in September 2007 at the State University in Voronezh (Russia).

- Similar tasks are being performed in the academic year 2007/2008 as well as the Board introduced other new initiatives:

- admitted new members to the "Center" from the countries of Central and Eastern Europe, which haven't represented in our organization before;

- together with Scientific Center of the Polish Academy of Sciences in Paris actively participated in organization of the VII ${ }^{\text {th }}$ international finance conference of Central and Eastern European countries, which took place in Paris on September 16-17, 2008, titled "The Basic Problems of Public Finance Reforms in the $21^{\text {st }}$ Century in Europe";

- began negotiations on the organization of the next international scientific conference, which is going to take place in September 2009 at the Faculty of Law of Ivan Franko National University of L'viv (Ukraine). 